\title{
Traditional Yoga Postures for Modern Geriatric Care Or Women's Yoga Lineages of the Lambourn Valley
}

\author{
Hilary Re'em
}

\begin{abstract}
This article is a personal reflection on the evolution of Yoga teaching and practice in the United Kingdom as I have experienced it growing up and growing old(er) in the Lambourn Valley in Berkshire, in the South West of England. I chart the development of a new style of Yoga Postures for Geriatric Care, describing some of the circumstances within which Yoga for the elderly has become increasingly meaningful. Along the way I will address the question of what in a modern tradition constitutes authentic practice, and what is the acceptable room for therapeutic innovation. Specifically, I ask, if pain and sickness are an obstacle to personal development should we try to transcend or to cure it?
\end{abstract}

\section{Keywords}

Yoga, self-cultivation, self-care, healthy ageing, BSK Iyengar, Lambourn Valley, pain, furniture Yoga, asana, ICTAM Bhutan

Yoga practice has meant different things to different people over time.

Inspired by IASTAM's spirit of bringing together historians, anthropologists and practitioners, what I will relate for you is my own history and impressions: those people and movements that have influenced me, and the observations I have made during the 35 years I have taught and practised Yoga in the Lambourn Valley in West Berkshire. I offer these thoughts hopefully not as a self indulgence, but as a contribution to the debate about authenticity as it relates to traditions passing from one place to another. After all, being in practice creates a different set of priorities to those that govern academic research, and the insights of practitioners might help in answering some of the core questions about innovation in tradition that historians and anthropologists seek to answer.

\section{My personal start, motivation and development}

In the mid-1970s, I was living with my son and a variety of animals in a small village on the banks of the Lambourn on the edge of an all-female Quaker 
community that was active in CND and in direct action against American presence in the military base at Greenham Common nearby. I was sculpting and painting, and learning techniques of potting. I was committed to energy conservation (I had no central heating), self-sufficiency (growing my own vegetables, raising chickens and milking the goats) and generally adopting an anti-materialist, anti-Conservative political and social agenda. In those days, my lifestyle and aspirations were generally looked on as rather radical, but nowadays would seem to be rather normal.

There was a Yoga class taking place in a nearby sports centre and I decided to go along and find out more. The sports centre was involved in that new wave of adult education that was becoming a national phenomenon at that time. Yoga was deemed a suitable subject for self improvement. It was bringing the fringe and fashionable passion for Asia that had been popular in the 1960s to the Home Counties and Middle England.

The teacher who was taking the class, Dorothy Payne, was registered with the Wheel of Yoga, the only local Society of Yoga professionals at the time, and the students were all women, wives of the Lambourn Valley in their 30s and 40s. As Newcombe notes, during the period from 1950 to 1979 women practitioners increased from 1,000 to $100,000 .{ }^{1}$ Women apparently made up perhaps $80 \%$ of Yoga classes at that time, and this is an accurate reflection of my student base today. The gender balance inevitably changes as we come to look at the teachers in the upper echelons of the various Societies. But why were we women at the grass roots?

Perhaps we can see the gender bias as a kind of national women's movement that is somehow opposite to that kind of physical Yoga that Joe Alter and others have seen allied to national fitness in India and the 'Muscular Christianity' of the late 19th and early 20th century. ${ }^{2}$ Yoga classes were a safe place and, in theory, offered a non-competitive physical activity that brought us the benefits of group exercise without an obvious hierarchy on the ground. We practised mainly in leotards and there were certainly the beginnings of that elegant atmosphere of 'health and beauty' that remains part of Yoga culture for women, now a global phenomenon, fashionable from Hollywood to Beijing. ${ }^{3}$ But in my experience, the conclusion that 'health and beauty' was all it was is an error made by academics who reconstruct reality from glossy representations in popular magazines without knowing much about what was really happening on the ground. Oral histories are needed to balance the image of women striking Yoga poses in fishnet tights.

${ }^{1}$ Newcombe 2007, p. 45.

2 Alter 2007.

${ }^{3}$ Newcombe 2007. 
That was some time before the Wheel of Yoga became the umbrella political organisation that it is today. In theory anyone who had or wanted to study Yoga could join and be placed on the register and so there was a wide variety of members - and the new teacher training courses were therefore run in a rather eclectic way that suited my temperament. As weekend courses, they attracted many women, who could train part time while looking after children.

The central teachings owed much to Annie Besant and her particular vision of socialism, women's rights and spiritualism, as had been espoused by the Theosophical Society through their interpretation of the work of Vivekananda. It seemed to be their influence, the Theosophists, and their commitment to cultural exchange between East and West that had brought the idea of cultivating 'mind, body and spirit' into Yoga. There also seemed to be a great deal of influence from the new psycho-therapies which, at least from the time of Jung, had had a fascination with Asian spirituality and inner alchemical practice. At that time, much was also invested in the spiritual leadership of Jiddu Krishnamurti, the one-time child guru.

In classes Dorothy Payne quoted from the Upanisads and the Bhagavad Gìtā to support her message that everyone could discover and act according to their true nature through the practice of Yoga.

It was an attractive message for those of us who were consciously breaking with past tradition in our own social lives and creating new lifestyles. So I tell my memories as I remember them and in the spirit of what they meant to me at the time.

We heard, for example, stories from Bhagavad Gìtā about Arjuna's dilemma whether to go into battle against friends and relatives. And how Krishna reassured him that he was a warrior and so had to act as that warrior. There are few if any explicit references to postural Yoga here in the ancient texts, but the lessons about being true to your own nature together with the physical practice were a heady mix for someone who was effectively 'dropping out' and choosing an alternative lifestyle.

Dorothy also drew inspiration from the image of warriors in the Upanisads. I particularly remember the image of reining the horse:

The roads that the horses follow are the paths; the reins are the sense; the chariot is the body and the charioteer is the mind.

Know that the Self is the rider and the body the chariot; that the intellect is the charioteer and the mind the reins. The senses, say the wise, are the horses, the roads they travel are the mazes of desire. The wise call the self the enjoyer when he is united with the body, the senses, and the mind. ${ }^{4}$

\footnotetext{
${ }^{4}$ Tr. Prabhavanda and Manchester 1948, p. 19.
} 
When the early Upanisads were written, the term 'Yoga' referred to the pursuit of immortality, but made no mention of physical fixed postures, breath control or introspective meditation. Rather, it occurred in two scenarios where the warrior was making an ascent to the highest realm of the heavens, by means of the suns rays/reins, to a place beyond the sun where the immortals were thought to reside. David White tells us that:

when warrior yogis who are 'yoked to Yoga' rise upward via the 'rays' of the sun, they are also doing so via the 'reins' of the sun (a god whose own chariot is pulled by seven steeds harnessed by seven rays/reins); and that when hermit yogis bind the bodies of other people with rays emitted from their eyes, they are also doing so with 'reins' emitted from their eyes. In both cases, Yoga is, emphatically, a matter of yoking one's person or self to something external to it: the gear of a nonmaterial chariot, the sun in the heavens, or the body of another person. ${ }^{5}$

Some of these images associated with early usage of the term 'Yoga' were assimilated to a much later tradition of postural Yoga, and survived to inspire me during the 1970s. At the time, I understood the practice to mean that you could use Yoga assanas as the reins to stimulate you out of inertia and acquired habits (samskaras), control restless activity and to guide you towards new creative paths.

I was also first introduced to B. K. S. Iyengar's teaching during that time. In his writings, he pays less attention to the Bhagavad Gìtā and Upanișads in favour of quoting liberally from Patañjali's Yoga Sütra and I have been most moved by reading his interpretations. I loved that agrarian vision of Yoga where the Yoga practitioner is likened to a farmer, selecting the fields he wants to irrigate by simply removing specific obstacles in the water course. ${ }^{6} \mathrm{We}$ imagined that by assuming assana postures you could do the same to the health and strength of your body in order to unleash your potential in a much broader sense. This was something that could also apply to teaching other people.

But such intelligence can only remove obstacles that obstruct certain changes. Its role is no more than that of a farmer who cuts a dam to allow water to flow into the field where it is needed. ${ }^{7}$

Nature's efficient cause does not impel its potentialities into action but helps to remove the obstacles to evolution, just as a farmer builds banks to irrigate his fields. ${ }^{8}$

5 White in Lo. (ed.) 2012, p. 131.

${ }^{6}$ Patañjali, Yoga Sütra 4.3, as interpreted by B. K. S. Iyengar 1993, p. 233.

7 Patañjali, Yoga Sütra 4.3. Tr. Desikachar 1995, p. 204.

${ }^{8}$ Patańjali, Yoga Sütra 4.3. Tr. Iyengar, 1993, p. 233. 
The agrarian module fitted perfectly with my lifestyle. I was spending a lot of time in the garden.

So I found out something new from those beginnings at the Wantage Sports Centre in the early 1970s, and afterwards in the class that began in the Quaker meeting house in East Garston where I lived, and perhaps it was not by accident. For it was all part of that movement among independent women and mothers to find new ways of seeing oneself and letting go of old habits and dependencies—-shedding the baggage left by our parents.

These were all core elements in the development of an alternative vision of how life could work in practice: a practice that was to become first and foremost daily regimen, then a social nexus and, critically, a way of survival in quite straightened circumstances, that complemented my existing lifestyle. Put together they provided me with self-determination, perhaps even a package of resistance to the pressures to conform that had been a part of growing up in the 1950 s, a self-determination that emerged in new community networks, and economies, and in my own body, obviating the need for capitulation to male doctors, orthodox religion, workplaces or any boss, basically. As Newcombe has said, 'Yoga served as an important support for women becoming more aware of feelings of alienation from traditional biomedical practitioners'.

By the late 1970s, the teacher at the Quaker Meeting house had moved on and I was persuaded to begin a three-year, once-a-month training course with the Wheel of Yoga. We had a set of books and had to write many essays. We would write on the Bhagavad Gittā and the Upanisads and how to do, and teach, Asana practice. For the latter, we used a translation of what we understood to be a fourteenth-century text which described äsanas, the Hatha Yoga Pradipika. The fact that the explanation of the àsanas was incomprehensible left a great deal of room for interpretation, both in our fantasies about what the book was about and how one might use it.

One essay that I remember most clearly was about why I was teaching, since it had happened by default and not as an active choice. I expressed some discomfort about teaching since teaching meant I did not get a good session myself and I disliked talking to groups anyway. However, I also wrote that what I wanted was for Yoga to 'happen' in the Lambourn Valley and for there to be 'someone to stand on one's shoulders'. It was prophetic as we shall see.

So you joined the society and got insurance when you were doing your teacher training and passed the exams. These were the beginnings of the standardisation and institutionalisation of modern Yoga in the UK. In reality, there was not much that was standard in our essays. It was more an exercise in imagining the kind of spiritual development that might be the benefit of a 
Yoga path. Yoga was part of a reorientation of values when faced with what we perceived to be a superior and, in the case of Gandhi's peaceful revolution, recently liberated, East and its apparently less materialist philosophy. All of this was of course digested with a large dose of Theosophy. However, most significantly, there was very little practice teaching äsanas.

After a few years I, and a group of women, including some of my students, realised that the teachers of the Wheel of Yoga were delivering a mishmash of various influences semi-digested, and delivered with some kind of airy fairy mysticism. At the time I wrote in my assessment of the course:

... the written work must be a great obstacle for anyone whose education or job has not prepared them for expressing themselves on paper. Another way students with something to offer may drop out is by being forced into a 'Wheel Mould'; obviously if one disagrees with half of this course there would not be much point in working for a Wheel diploma. But, that said, most students will find areas that [...] they cannot accept or that they may not have assimilated. At best they cannot teach these areas convincingly, and at worst they are being put in to a false position.... In practice some tutors seem to have an attitude as rigid as that which they accuse... the Iyengar method of having.

The teachers were sincere and had helped me immensely in my life, but with some experience behind me it seemed to me that the postures were woolly. Some of us began to look for something more 'authentic' and coherent. That came quite quickly in the Yoga teachings of B. K. S. Iyengar as I experienced them through his teachers.

Iyengar's more powerful and physically-grounded methods suited my practi$\mathrm{cal}$, farming nature. Rather than working on following some elusive spiritual path we could train our bodies as the primary tool and the rest would fall into place. We also had two really good Iyengar teachers move into the Lambourn area. They shared a new precision that we had never encountered before-a precision that exposed my former training not for being free and easy, but for being sloppy.

There was Nancy Bayes who, like me, had also begun with the Wheel of Yoga. Her very being seemed to be well-structured. And there was Paquita Claridge who brought precision and system to her work. I had irregular contact, but I was inspired by the simplicity of the new message as put succinctly by my first Iyengar Yoga teacher, a Yorkshire woman, Helen Davey: 'sit on your sit bones'. To me all these Iyengar teachers had gravitas, they were stronger, sturdier people.

There was a hard core in Iyengar's techniques that made it more 'down to earth' somehow, more physically challenging. The aura of 'authenticity', of course, came from him being Indian and closer to the source culture, and perhaps, thereby appealed to a broader base of people. 


\section{Women's Yoga lineages of the Lambourn Valley}

Taking teacher training classes with Iyengar teachers meant that we all had to teach postures, observing and presenting them better each time. My student Judith Jones became exceptionally clear at linking all the points of the practice making each posture relevant to the next one in a sequence. She soon became my teacher. With the alignment of the poses at the core of the class there was less meditation involved. We were told that for $\mathrm{Mr}$ Iyengar when a posture and one's mind became focused, and the breathing steady, the meditation would come of its own accord.

I personally never qualified as an Iyengar teacher, and never cared much to qualify. I retain a natural suspicion of the politics and hierarchies of organisations in the alternative sector that are concerned with purity of lineage. Judith, who fulfilled the aims that I set for myself in my Wheel of Yoga essay, took over my teaching in adult education in Lambourn and the surrounding towns, and became the president of the Iyengar organisation in the UK. She is very concerned about the authenticity of Yoga postures according to an orthodox doctrine. Authenticity in this sense means rigorous techniques that do not diverge from an orthodox standard.

But Iyengar says that in his 90s he is still learning. As you can see through studying the difference between Mr Iyengar's two books, Light on Yoga (1966) and The Path to Holistic Health (2001), Iyengar Yoga has become increasingly medical, both curatively and preventively. Over these 50 years there are more claims to be able to heal parts of the body that have been injured or neglected as well as to enable the systems of the body to function effectively and as efficiently as possible. ${ }^{9}$

The first book, Light on Yoga, is a guide for getting fit and supple for the fit. To be sure he does describe a sequence of some 80 postures for different ailments such as flatulence in a 20-page appendix. ${ }^{10}$ But the explanations for the illustrations are given some way away and many of the postures are very difficult. By the time of Path to Holistic Health, there are 100 pages of therapeutic postures within the main text and the structure of the layout makes the book much more practical for teaching and self-help. ${ }^{11}$

Iyengar himself had been a very weak and sickly child until he came under the tutelage of his brother-in-law Krishnamacharya, and it seems that over the years he paid more attention to effective, inclusive teaching. So the latter book

\footnotetext{
9 Iyenger 2001, p. 237.

10 Iyengar 1966, Appendix 2 'Curative āsanas for various diseases', pp. 486-506.

11 Iyengar 2001, ch. 5, 'Yoga for Ailments', pp. 237-383.
} 
on holistic health has at least 100 specific sequences arranged according to illness categories with a picture for each of the postures. ${ }^{12}$ It is much easier to follow and, in theory, is intended for anyone to do.

Most of my information on geriatric care comes from Iyengar, and his work between his 1954 and 2005 publications as he made his skills fit a new community of less able practitioners. In the later book, Light on Life, Iyengar quotes a great deal from Patañjali's Yoga Sütra, emphasising that the first obstacle on the Yoga path is illness, and that illness disturbs the mind. These physical impediments apparently make progress difficult on our Yoga journey and the Iyengar approach is first to cure them where possible, and then to sublimate where not possible.

In Light on Yoga (1966) there is no evidence of Yoga props to help those who are in advanced illness or old age. In Path to Holistic Health (2001), however, he dedicates a section to äsana with props and calls on tradition to underwrite his new interest:

Ancient yogis used logs of wood, stones, and ropes to help them practise āsana's effectively. Extending this principle Yogacharya invented props which allow asanas to be held easily and for a longer duration, without strain. ${ }^{13}$

When Mr Iyengar started to help his remedial students with props initially it was referred to by sceptics disparagingly as 'furniture Yoga', which meant to suggest that it had a rather mundane quality introduced by targeting the less fit and able and those less likely to achieve transcendence. ${ }^{14}$ But, actually, it is rather a good title.

That all began 35 years ago. Now to me Yoga is a way of life, as it is to many of my contemporaries with whom I have grown old, and many of whom I teach. We have experienced together the benefit of Yoga to what we have understood to be our mind, body and spirit, and some of us are still in pretty good shape despite debilitating illnesses. Others are not. Our work is ever more important as people deteriorate physically. Those people who have sustained practising Yoga over a prolonged period seem better able to manage their decline. Having micro-managed their bodies throughout their lives, they have developed skills for dealing with pain by themselves, or within their Yoga communities. Taking up śavāsana, the corpse pose, also helps us deal with the fear of death. ${ }^{15}$ When you play dead it is like surrendering the boundaries of your body to the earth and letting go of any attachment to life. When you do

12 Iyengar 2001, pp. 242-383.

13 Iyengar 2001, p. 164.

14 The disparaging of those thought lower down the scale on the 'transcendence' hierarchy is an age-old pursuit! See Dear, this volume, p. 25.

15 Iyengar 2005, p. 195. 
that daily it is surely a ritual preparation that, through daily repetition, prepares you for the end. As Vanda Scaravelli, a student of Iyengar's, states, 'to die is alright, we all have to sooner or later, but what we must do is not allow the body to degenerate while living. ${ }^{16}$ To an extent I agree, but Scaravelli is optimistic. What most of the elderly have to deal with is greater or lesser degeneration and the challenge to sustain functionality.

The King's Fund Report on end-of-life care told us in 2010 that two thirds of people in the UK preferred to die at home, but that only $18 \%$ of us in fact did. Quoting the Rand Report, it highlights the potential cost savings of dying at home that would come from reduced expenditure associated with hospitalisation. Apparently the health costs of the last year of your life are as much as half the rest of your lifetime. ${ }^{17}$ Modern Yoga can help us face the fear of death and gives us strategies for coping with decline. Evidence for the health benefits of exercise have been well known since the 1950s, although it took 50 years for sufficient appropriate knowledge to accumulate to enable those responsible for formulating public health policy to take meaningful action. ${ }^{18}$ Target levels of physical activity were set in 2004 and 2011 by the Departments of Health in the UK. ${ }^{19}$ There is, however, no evidence that public policy aimed at whole populations has had any success in getting people moving at all.

The latter half of the twentieth century was also the period during which Yoga was becoming a significant global movement, and those young people of the 60s and 70s who were fascinated by the lifestyle and practice that it offered now constitute a large part of the increasing number of elderly people in the UK. Thus we can know, by virtue of their very numbers, that the everincreasing healthcare costs of an ageing population have been reduced and the mental and physical well-being of the individual practitioner improved by regular Yoga practice. At the same time, self-care can go some way to accommodate the expressed preferences of the majority of the population who we know want to stay out of hospital.

As the success of Saga holidays for the elderly demonstrates, we are older with higher aspirations for the maintenance of our youth and mobility. We also have more symptoms to deal with and more time on our hands. In the UK, older students may seem privileged — many not having pressing material needs—but life is also not always easy for them. If they have not been lifelong practitioners it can be a brave move for people in middle to old age to take their first step on a Yoga journey. They have all kinds of motivations. The older often means the

\footnotetext{
16 Scaravelli 1991, p. 38.

${ }^{17}$ Hatziandreu et al. 2008; King's Fund 2010, p. 18; National Audit Office 2008, p. 3.

${ }^{18}$ Renton and Philips 2012.

19 Chief Medical Officer 2004; Chief Medical Officers of England, Scotland, Wales, and Northern Ireland 2011.
} 
more pragmatic, with elderly people looking for practical help for bad backs and dodgy knees. The spiritual path is for them a luxury, and in any case, release from the material body is imminent! They simply want to feel better, to sort out their individual condition and its range of discomforts.

Yoga helps with a variety of symptoms as I have observed in myself, or have seen in students, or had reported by others.

- Exercises to tighten your pelvic floor muscles help with incontinence.

- General weight-bearing exercises, we are told, strengthen the bones and obviate the need for hip replacements.

- Better balance and body awareness prevents accidents and helps poststroke recovery.

- Daily Yoga practice eases sleeping and increases the appetite and digestion.

- Daily Yoga improves the cardiovascular system and all the benefits that brings.

Some of these effects are only the result of sustained practice. But the initial Yoga class is aided by the usual feelings of well-being induced immediately. There are also other possibly indirect, but also immediate benefits:

- Gaining a greater control over their bodies empowers old people generally in their lives.

- Social networks around the classes provide friendship and understanding reducing depression and anxiety.

In all these ways Yoga can give fortitude to reduce the suffering of illness and fear of mortality. As Iyengar says, Yoga is for everyone. There is an asana to suit every constitution irrespective of age or physical health. ${ }^{20}$

\section{Innovation in the practice of Yoga äsana for the aged}

So here is the central question that I brought to the panel in Bhutan. If, as Mr Iyengar has done, it is possible to develop the tradition and make it relevant to a rapidly increasing elderly community he endorses the tailoring of tradition for the greater good of mankind. But, then, what is the acceptable ground for innovation, the acceptable conditions for developing a tradition? One can hardly claim the authority and skill of Iyengar, and much of what

${ }^{20}$ Iyengar 2001, p. 16. See also Kirkwood et al. 2005 and Bonura 2007 for modern studies that show encouraging findings on Yoga for psychological health. 


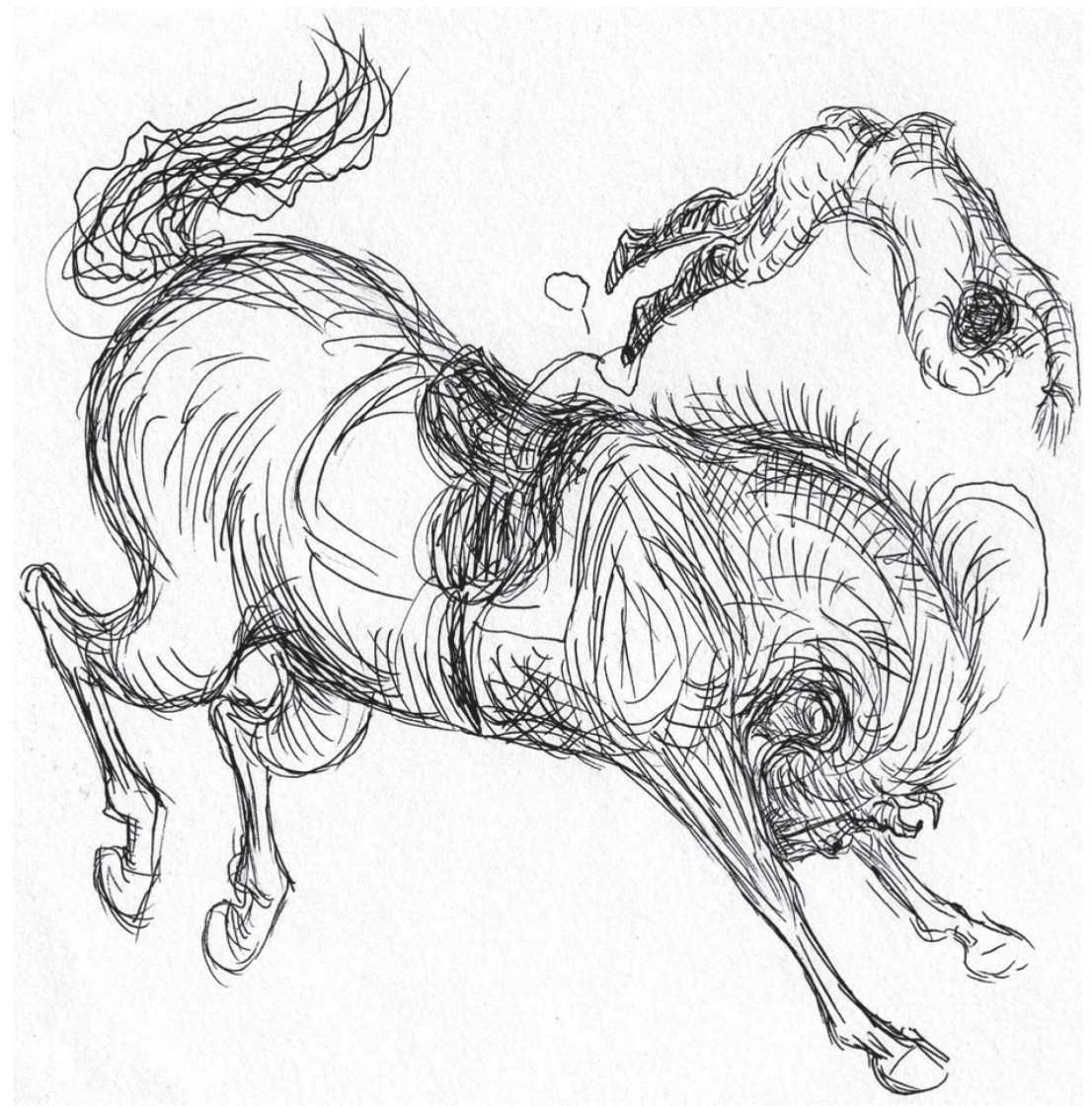

Fig. 1. The Fall

actually gains credence is by virtue of the prevailing authorities, a matter of power politics and fashion. In the light of this, my analysis has modest pretensions, but I believe it is timely inasmuch it addresses an urgent need for geriatric care that has, only in the last decade, begun to attract the attention of policy-makers.

One element that you bring to any formal education that you have had in therapeutic Yoga is your own experience, of your own discomfort and injury, and that forms one aspect of how innovation happens in therapy. Figure 2 shows me practising what I preach after falling from a crazy Marwari horse in Rajasthan the week before the ICTAM VII and figuring out ways of dealing with those specific bumps and bruises. 


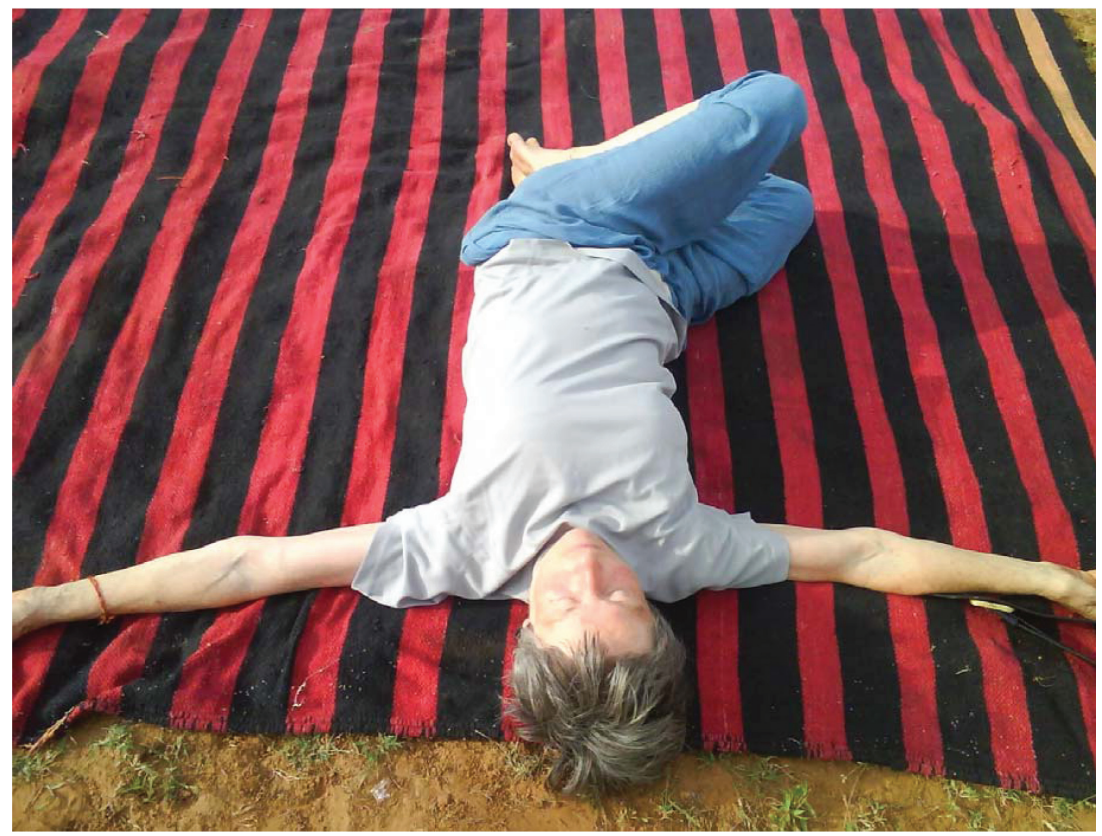

Fig. 2. Bruised in Rajasthan

Sadly I did not have any ropes, because hanging upside down, as I do every day at home, would have surely alleviated the pressure in my back.

When working with elderly people, it is inevitable that they have a whole range of different symptoms all of which have to be taken into account at any one time-and it is in this process that one comes up with new and unique combinations of treatment in every class. This involves on the one hand likening their problems to your own, and on the other comparing successes and failures with other sufferers with whom you have worked, and what you have learned from their feedback. On this basis, you put together a package of treatment for each individual. All these things involve creativity and innovation. With subtle awareness of their bodies, experienced practitioners, as they age, can maintain their range of āsana practice, with firm but relaxed postures. The floor, walls, chairs and tables that are in everyday use in their own homes can steady the standing postures, align the twists, support the back bends and relax the forward bends. All this can also enable Inverted poses. This is not just a soft option, it can be a deep and subtle practice for anyone, however limited and disabled.

Since there are never textbook people and every individual and their bodies are so different, you have to adapt postures beyond the formal set. I regularly 


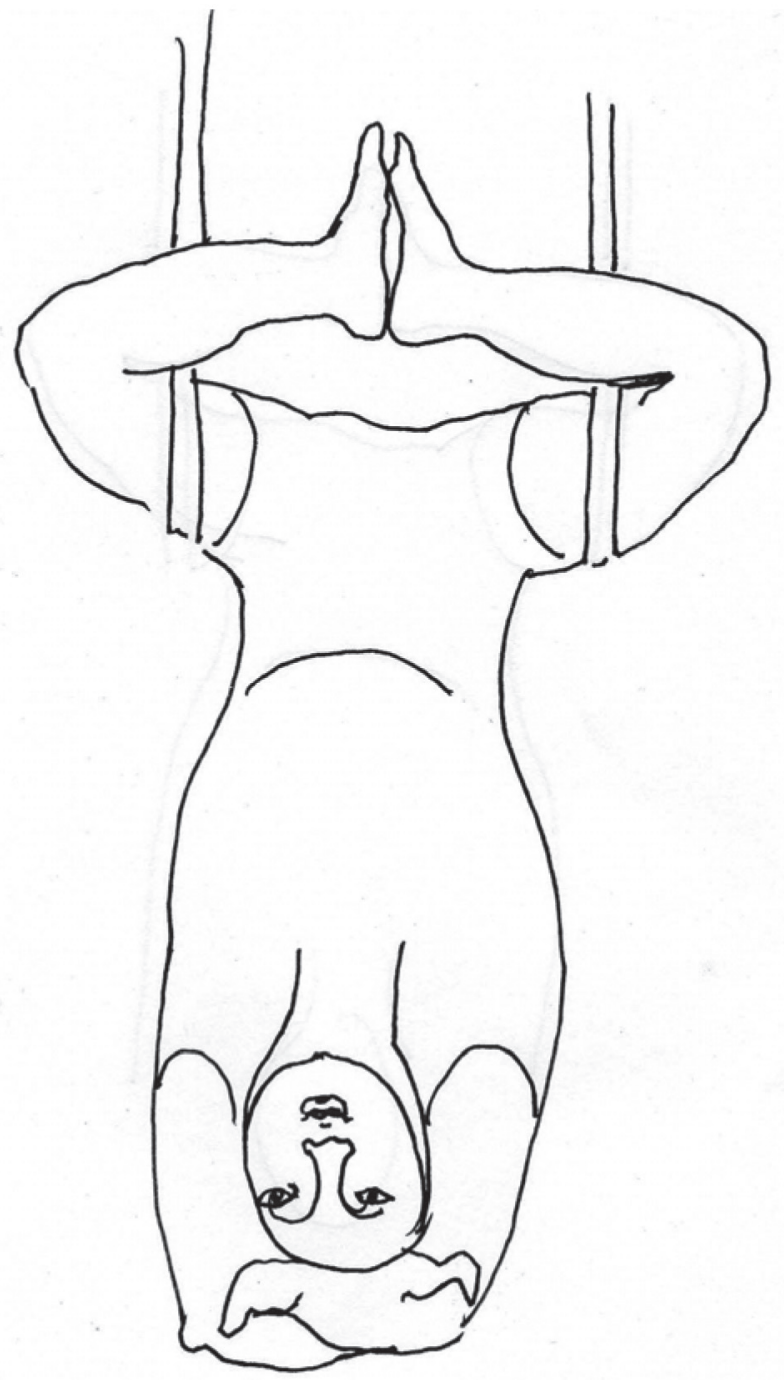

Fig. 3. Hanging upside down 
use my own furniture and enquire about the geography of a sufferer's house to see what remedies there are directly to hand.

Let us take one example and see how it pans out:

\section{Trikoṇāsana}

The Wheel of Yoga style has simple instructions:

Bend to one side: one arm up and one arm down

Iyengar adds precise details about:

- Placement of the feet

- Straightness of the legs

- Attention to knee caps

- Keeping the front leg turned 90 degrees outward

- The back thigh pressed back, so the hip has not swung forwards.

- The chest facing forwards with even stretch each side of the waist so the spine remains straight over the front leg

- Equal weight on both feet

- Where you look and how you breathe

I add that if there is pain in the knee, a prop under the foot will facilitate the posture.

Here, finally, is a case study of a specific student of mine:

A particular lady in her 80s fell down the stairs and damaged her sacrum. She began to drop on one side and her shoulder was compressed. First of all I directed her to practise breathing into the collar bone. Full uttānāsana would have involved a complete forward bend, so we tried out a Half uttānāsana over a table. Then she pressed down on four corners of the feet, with the four corners of the knees pulled up and the legs pressed back and leg bones parallel. I placed a weight on her sacrum while she stretched out along the table evenly (some people who have developed their practice can stretch and raise one leg backward to the horizontal).

This adjusted Half uttānāsana protects the lumbar and sacrum from overstretching and straining, especially when returning the body to the standing position from that posture. It is fine to stay in that posture for five minutes. In winter time it is good to insulate the back and keep it warm by adding a weight. Polystyrene is very insulating and keeps the warmth. Furniture Yoga not only makes sustaining into, or taking up Yoga in old age possible. It also provides the teacher and sufferer with time to observe the subtleties of the 


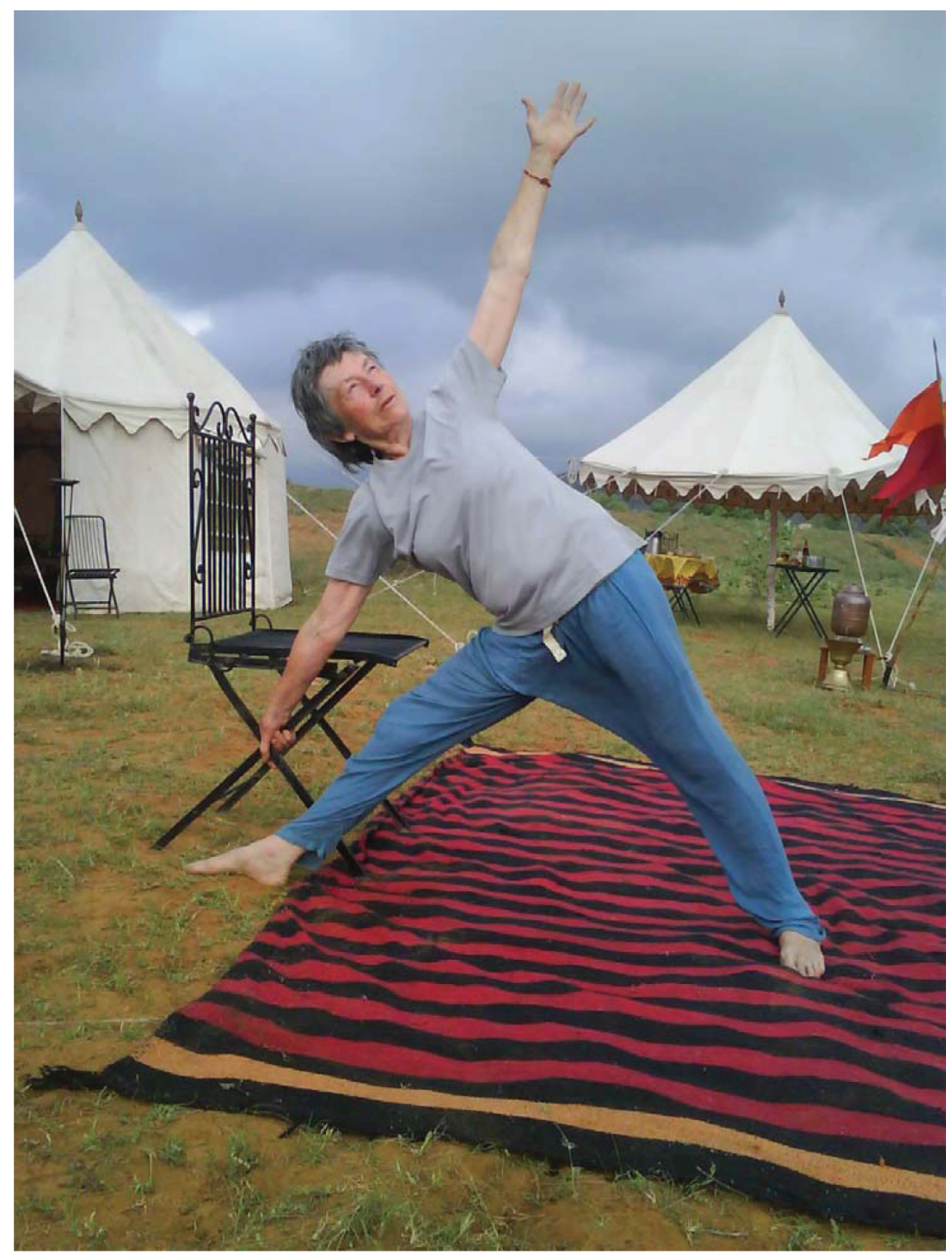

Fig. 4. Trikoṇāsana 


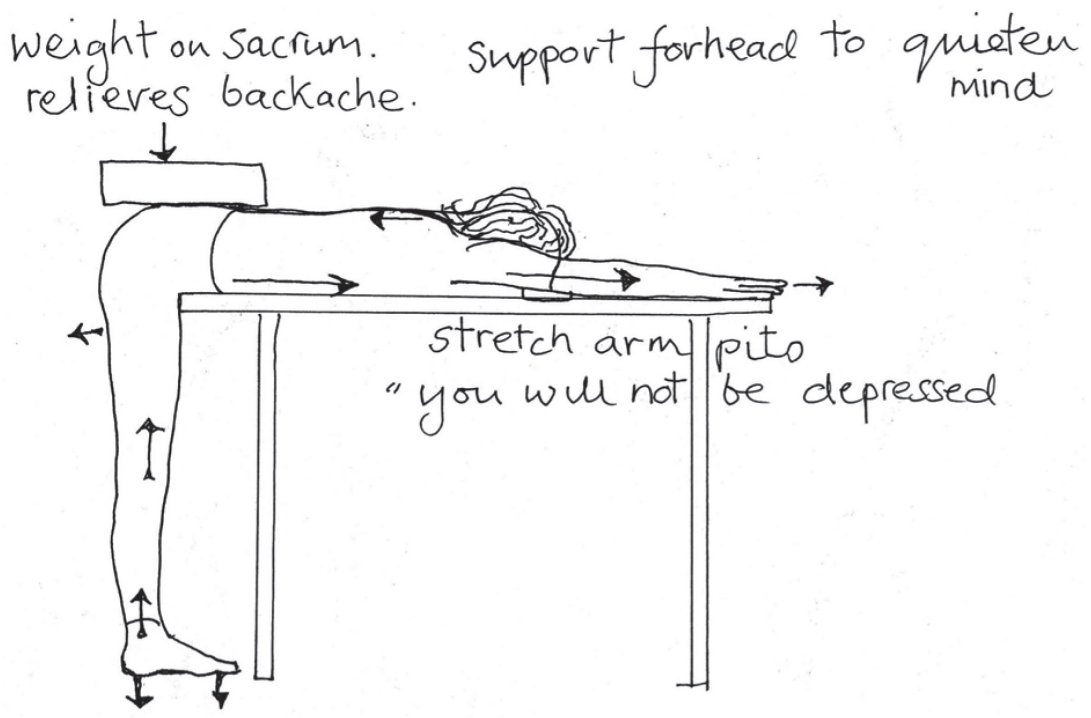

Fig. 5. Furniture uttānāsana

patient's discomfort and allows adaptation. There is time for an ever-emerging feedback loop to develop between sufferer and teacher.

\section{Summary}

In the course of this short essay, we have moved from Health and Beauty through Eastern mysticism to Remedial Yoga in geriatric care. As Elizabeth De Michelis points out, 'Even if practitioners' commitments and beliefs are differently structured, it is likely that [modern postural Yoga] will be able to offer some solace, physical, psychological or spiritual, in a world where solace and reassurance are sometimes elusive', or simply, as Mr Iyengar says, 'you can still tie your shoelaces up' even if you cannot do the backbends that he still does at $80 .{ }^{21}$ But if a tradition is in rapid transformation, changing its methods, its aims and its names, how does it remain authentic to the true traditions of a particular teacher:

- by retaining a core stability to techniques or principles over time?

- by delivering an appropriate and authentic therapy that the sufferer can relate to?

${ }^{21}$ De Michelis 2006, p. 260. 


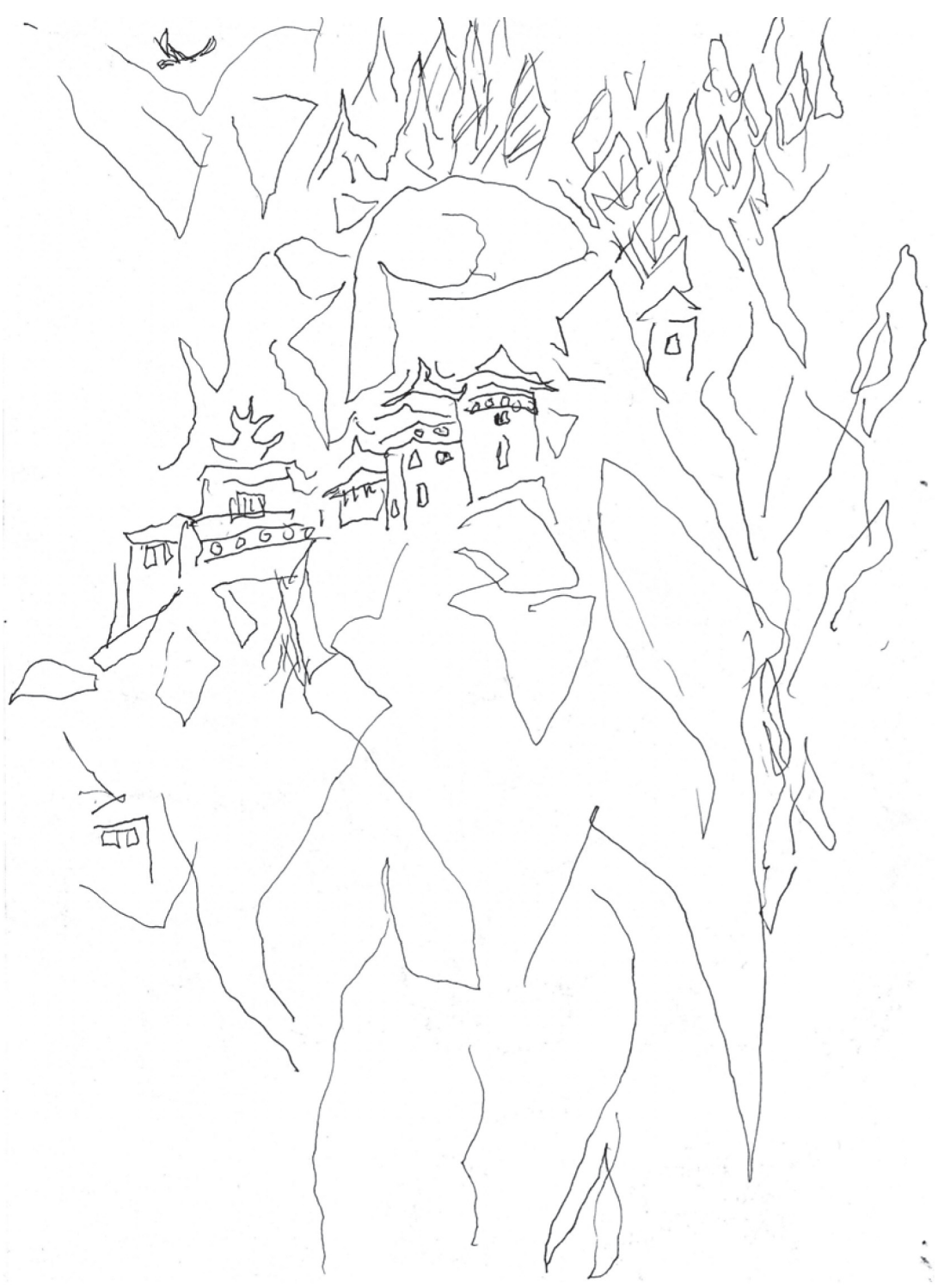

Fig. 6. The Taktsang Monastery, Paro, Bhutan 
These are different meanings of authenticity. Some elements of tradition need to achieve a certain stability, such as the principles of the authentic 'Iyengar tradition' as promulgated by my student and teacher, Judith Jones. But the paradox is that there is also authenticity in the fact that tradition changes and transforms to keep becoming itself. If it did not, it would never make it to become a tradition. If it became fixed as an immutable body of knowledge it would become irrelevant and redundant very quickly.

Since this is the case, authenticity must be found in change, and I have suggested several ways in which I understand the conditions are ripe for tailoring a tradition:

- There has to be a new audience.

- The new therapy must meet this need.

- There must be time for a feedback loop to develop between students and teacher, so the knowledge is cooperative. Iyengar took some 25 years himself to systematise his experience.

- The innovating teacher must him or herself have invested sustained and energetic interest in practice and be committed to ongoing self-education.

- Any change should happen slowly with time for adjustment.

- There must be a concentrated engagement with history which might mean:
a) drawing on past personal experience
b) drawing on therapeutic experience
c) reading classical texts, comparing translations

For the latter, we rely on the work of historians and philologists to tell us more about the deep background of our tradition, to give us a good translation and study of the social and cultural background to Patañjali, so we can make informed decisions about what remains relevant to us. It was a great honour to be able to speak in Bhutan, a place where many of the same important issues about the value of tradition and its meaning in the contemporary world were also on the agenda.

\section{References}

Alter, J. 2007, 'Yoga and Physical Education: Swami Kuvalayandanda's Nationalistic project', Asian Medicine, 3.1: 20-36.

Appleby, J., C. Ham, C. Imision and M. Jennings 2010, The Kings Fund Report: Improving NHS Productivity: More with the Same not more of the Same, London: The King's Fund. 
Bonura, K. B. 2007, 'The Impact of Yoga on Psychological Health in Older Adults', Florida State University, Electronic Theses, Treatises and Dissertations, Paper 3549.

Chief Medical Officer 2004, At Least Five a Week: Evidence on the Impact of Physical Activity and its Relationship to Health, London Department of Health.

Chief Medical Officers of England, Scotland, Wales, and Northern Ireland 2011, Start Active, Stay Active: A Report on Physical Activity from the Four Home Countries, London: Department of Health.

De Michelis, E. 2006 [2004], A History of Modern Yoga, London: Continuum.

Desikachar, T. K. V. 1995, The Heart of Yoga: Developing a Personal Practice, Rochester: Inner Traditions International.

Hatziandreu, E. F. Archontakis and A. Daly 2008, The Potential Cost Savings of Greater Use of Home and Hospice-based End-of-life Care in England, http://www.rand.org/pubs/technical_ reports/TR642.html (accessed 10/11/2012).

Iyengar, B. K. S. 1979 [1966], Light on Yoga, London: George Allen and Unwin.

-1993, Light on the Yoga Sütras of Patañjali, London: The Aquarian Press.

. 2001, The Path to Holistic Health, London: Dorling Kindersley.

- 2005, Light on Life, London: Rodale.

Kirkwood, G., H. Rampes, V. Tuffrey, J. Richardson and K. Pilkington 2005, 'Yoga for Anxiety: A Systematic Review of the Research Evidence', Br J Sports Med, 39: 884-91.

Lo, V. (ed.) 2012, Perfect Bodies: Sports Medicine and Immortality, London: British Museum Research Publications.

National Audit Office, 26 November 2008, 'End-of-life Care', http://www.nao.org.uk/publications/0708/end_of_life_care.aspx (accessed 10/10/2012).

Newcombe, S. 2007, 'Searching for Health and Well-being: Yoga and Women in Britain, 1960-80', Asian Medicine, 3.1: 37-63.

Renton, A. and G. Phillips 2012, 'Exercise and the Health of the Public', in V. Lo (ed.), Perfect Bodies: Sports Medicine and Immortality, London: British Museum Research Publications, $163-7$.

Scaravelli, V. 1991, Awakening the Spine, New York, Harper Collins.

Upanishads, Tr. Swami Prabhavanda and Frederick Manchester 1948, The Upanishads: Breath of the Eternal, New York: New American Library.

White, D. G. 2012, 'The End of Yogis', in V. Lo (ed.), Perfect Bodies: Sports Medicine and Immortality, London: British Museum Research Publications, 129-34. 